\title{
A Execução Forçada do Ato Administrativo Unilateral 35.077 .2
}

\section{TOMÁs DE Vilanova MONTEIRo LOPES}

A executoriedade, como é sabido, constitui um dos mais significativos característicos do atc administrativo unilateral. Por ela se explica o fato de, em determinadas circunstâncias, dispor a administração da vis compulsiva e poder ela mesma, desde logo, sem prévia intervenção do Poder Judiciário, compelir à obediência o particular recalcitrante.

Todavia, a execução forçada do ato administrativo unilateral não quebra c sistema de legalidade e está sujeito a certas condições que a justificam e the dão legitimidade.

E' preciso, antes de mais nada, que o particular oponha resistência ao ato administrativo; que, por ação ou omissão, concretize o propósito de desobedecê-lo. Sem essa resistência a execução forçada seria um excesso injustificável, uma violência. De fato, se, como veremos mais adiante, a decisão executória, em tese, só tem cabimento ante a impossibilidade da realização do ato administrativo por outro meio jurídico, é evidente que ela se tơrna ilegítima, quando nenhum obstáculo o particular opõe à administração. $\mathrm{Na}$ defesa de tal princípic; que é consagrado pelo consensus omnium, certos autores levam sua severidade ao ponto de não admitir que se presuma a resistência do particular ao ato administrativo.

LAUBADÈRE sintetiza os casos legítimc's de execuçãço forçada do ato administrativo unilateral em três itens:

$\left.1 .^{\circ}\right)$ Autorização legal

$2 .^{\circ}$ ) Inexistência de outro meio jurídico

$3 .^{\circ}$ ) Urgência.

A hipótese de autorização legal é de tôdas as mais fácil de ser estudada, porque não comporta maiores controvérsias. Quando autoriza a administração a tomar respeito de certas matérias decisões executórias a lei não apenas imprime a essas decisões o cunho de juridicidade, como também retira ao particular a chance de contestar com êxito o seu emprêgo.

Evidentemente, porque se trata de uma simples autorização legal não fica a administração obrigada a tomar a decisão executória; toma-la-á se a considerar oportuna ou conveniente, usando de seu poder descricionário.

Ao pärticular não cabe eleger a maneira de execução do ato, pois tanto importaria em investir-se êle numa faculdade que, sendo privativa da administração pública não se defere nem mesmo ao Poder Judiciário. No jul- 
gamento da conveniência ou oportunidade do meio a empregar, dentre os que a lei admite, para atingir os fins do serviço público a administração é soberana, e dêste princípio decorrem limitaçôes ao alcance do contrôle jurisdicional dos atos administrativos. Não seria, pcrtanto, de admitir-se, nessa matéria, a predominância do interêsse particuiar.

Será necessário que a autorização legal para prática da decisão executória seja sempre tao expressa? Não nos parece digno de adesão o pcnto de vista dos que respondem pela afirmativa. Com efeito, há casos em que, mesIno sem autorização legal expressa, pode a administração tomar decisöes executórias. Em tais cascs se configura uma autorização legal implícita, criunda do fato de que a lei deve sempre ter assegurada sua execução, ou do reconhecimento de que, em circunstância especiais, para não deixar de atender a interêsse público urgente, a administração não apenas pode, mas deve recorrer à execução forçada de seus atos.

Pode acontecer que a ausência da citada autorização legal coincida ccm a indicação de outros meios jurídicos capazes de compelirem o particular à obediência do ato administrativo. Em semelhante hipótese, a própria vontade da lei, traduzida na preferência expressa por outros meios jurídiccs, exclui a decisäo executória, vinculando a administração à preferência manifestada pelo legislador.

Matéria cujos contornos vêm sendo traçados pela jurisprudência, nem sempre sem uma certa vacilação, a existência de outros meios jurídicos capazes de excluir a decisão forçada ainda não chegou a ser cbjeto de um sistema, permanecendo, até agora, como simples produto de uma elaboração constante da experiência.

Admite-se, em geral, que êsses outros meios jurídicos existem quando a lei prescreve sanções para us casos de resistência ao ato adminitrativo, ou estabelece qualquer modalidade de ação judiciária em favor da administração contra o particular rebelde. Assim, por exemplc', se administração pode valer-se da ação penal ou mesmo da ação civil, a execução forçada do seu ato deixa de ter cabimento.

LEON BLuM resumiu com suficiente clareza a norma geral que deve presidir a matéria, dizendo que

L'executino administrative n'est pas justifiée en principe que par la necessité d'assurer l'obeissance á la loi et l'impossibilité de l'assurer par tout autre procedé juridique.

A exatidão dessa norma se evidencia quando a confrontamos com a definição, soje clássica, que ROMIEU que identifica na execução forçada "um meio empíricc, legalmente justificado, a falta de outro procedimento, pela necessidade de garantir a obediência à lei".

Mas, ainda que não se verifique a autorização legal e estejam previstos oútros meios jurídicos, a execução forçada não configura um procedimento irregular, quando fundada na urgência da manutenção da ordem ou da garantia do andamento dos serviços públicos.

Para explicar êsse processo de substituição da legalidade normal, por uma legalidade de exceção, a jurisprudência administrativa, primeiro, 
e, em seguida, a jurisprudência civil construiram a teoria dos pciêres excepcionais, segundo a qual certas decisões administrativas que, em épccas normais padeceriam da eiva de ilegalidade, se tornam legítimas em determinadas circunstâncias, por isso que se acaso não fôssem tomadas graves danos se produziriam.

Pode parecer à primeira vista que a teoria dos podêres excepcionais não é senão um caso especial da aplicação da idéia de estado de necessidade; mas, se a examinarmos menos superficialmente, veremos que, em realidade, ela decorre do dever fundamental da administração para com a ordem e os serviços públicos.

O próprio fundamento dos podêres excepcionais encerra os critérios para o estabelecimento das limitações a que tais podêres estão sujeitos. Evidentemente se êles emergem de circunstâncias especiais devem cessar de existir quando estas desaparecem e a recomposição da normalidade impõe o retôrno ao regime da legalidade comum.

Por outro lado a administração, no exercício dos podêres excepcionais deve adstringir-se às medidas realmente reclamadas pelo interêsse público, não podendo, sob qualquer pretexto, excedê-las. Isso acontece porque a atividade administrativa, quando envolve 0 uso dos podêres excepcionais, é vinculada, e, como tal, sujeita ao contrôle jurisdicional pleno.

Ainda hoje se discute o papel da publicidade na decisão executória, entendendo uns que esta sem aquela será fulminada por defeito de forma; sustentando outros que não sendo a publicidade um elemento integrativo da decisão executória sua falta não poderá produzir tão grave efeito.

Parece-nos que a matéria se delucida mais fàcilmente, quando orientamos nosso raciocínio partindo das hipóteses distintas da publicidade anterior, concomitante e posterior ac ato, porque então se torna evidente que só nas duas primeiras hipóteses pode a publicidade constituir elemento integrativc do mesmo ato. A publicidade posterior se faz em relação a um ato completo e acabado, que mesmo sem ela se concretiza com tôdas as características que the são peculiares. Em tal hipótese, será demasia falar em publicidade como elemento integrativo da decisão executória.

Daí, entretanto, não se segue que a publicidade posterior à decisão executória é uma formalidade inútil. Não. Ela se faz necessária para efeito de oponibilidade contra terceircs, ou seja, no caso, contra os particulares. A decisão executória não publicada é válida, apenas não é oponível ao particular que dela não foi notificado regularmente. 